\title{
KARAKTERISTIK MORFOLOGI DAN ANATOMI JAHE (ZINGIBER OFFICINALE) BERDASARKAN PERBEDAAN KETINGGIAN TEMPAT
}

\author{
Mareta Widiya $^{1}$, Ria Dwi Jayati ${ }^{2}$, Hevi Fitriani $^{3}$ \\ STKIP PGRI Lubuklinggau ${ }^{1,2,3}$ \\ maretawidiya@gmail.com ${ }^{1}$
}

\begin{abstract}
ABSTRAK
Tujuan penelitian ini adalah untuk mengetahui perbedaan morfologi dan anatomi tanaman jahe berdasarkan perbedaan ketinggian tempat, dan membuat sebuah booklet hasil karakteristik morfologi dan anatomi jahe untuk mata kuliah morfologi dan anatomi tumbuhan. Metode penelitian ini yaitu metode penelitian kualitatif. Teknik pengumpulan data dalam penelitian ini melalui observasi, wawancara, teknik karakterisasi, kajian dokumen, dan kuesioner atau angket. Teknik analisis data dengan analisis deskriptif dan deskriptif kuantitatif. Hasil penelitian, adanya perbedaan karakteristik morfologi dan anatomi jahe berdasarkan perbedaan ketinggian tempat, tanaman jahe di Kecamatan Tugumulyo memiliki daun terpanjang dan terlebar, batang tertinggi, akar terpanjang, rimpang terpanjang dan terlebar, dan warna daun dan batang yang hijau pekat. Tanaman jahe di Kecamatan Selupu Rejang memiliki kerapatan stomata yang tinggi. Tanaman jahe lebih cocok ditanam di dataran rendah dengan suhu udara tinggi, kelembaban yang rendah. Penyusunan dan pembuatan booklet mata kuliah morfologi dan anatomi tumbuhan dinyatakan valid dengan kualifikasi sangat layak dengan persentase $86,2 \%$. Simpulan, ada perbedaan karakteristik morfologi dan anatomi tanaman jahe berdasarkan ketinggian tempat, adapun booklet yang dibuat memiliki kualifikasi layak dan valid untuk digunakan sebagai bahan mata kuliah morfologi dan anatomi tumbuhan.
\end{abstract}

Kata Kunci: anatomi, jahe, karakteristik, morfologi

\begin{abstract}
The purpose of this study was to determine the differences in the morphology and anatomy of ginger plants based on differences in altitude, and to make a booklet resulting from the morphological and anatomical characteristics of ginger for morphology and plant anatomy courses. This research method is a qualitative research method. Data collection techniques in this study through observation, interviews, characterization techniques, document review, and questionnaires or questionnaires. Data analysis techniques with quantitative descriptive and descriptive analysis. The results of the study showed that there were differences in the morphological and anatomical characteristics of ginger based on differences in the height of the place. Ginger in Selupu Rejang District has a high stomata density. Ginger is more suitable for planting in the lowlands with high temperatures, low humidity. The compilation and manufacture of morphology and plant anatomy course booklets were declared valid with very decent qualifications with a percentage of $86.2 \%$. Conclusion, there are differences in the
\end{abstract}


morphological and anatomical characteristics of the ginger plant based on the height of the place, while the booklets that are made have proper and valid qualifications to be used as material for plant morphology and anatomy courses.

Keywords: anatomy, ginger, characteristics, morphology

\section{PENDAHULUAN}

Biologi adalah bagian dari ilmu pengetahuan alam (IPA), kajiannya berhubungan dengan makhluk hidup serta proses-proses kehidupannya. Biologi mengkaji semua makhluk hidup, dari yang hidup di masa lampau hingga masa kini. Biologi bukanlah ilmu tunggal, tetapi berupa ilmu multidisipliner yang berkaitan dengan ilmu-ilmu lainnya (Warianto, 2011). Biologi memiliki cabangcabang ilmu diantaranya morfologi dan anatomi.

Morfologi dan anatomi tumbuhan merupakan cabang ilmu biologi yang kajiannya yang tidak sama tetapi saling berhubungan (Farm africa, 2013). Morfologi tumbuhan merupakan ilmu yang mempelajari bentuk serta susunan luar tumbuhan. Sedangkan anatomi tumbuhan merupakan ilmu yang mempelajari susunan dalam tumbuhan (Sa'adah, 2015). Karakteristik morfologi tumbuhan yang bisa diamati antara lain bagian-bagian daun dan bentuknya, tipe daun, tata letak daun, bentuk batang, arah tumbuh batang, percabangan batang, sistem perakaran serta bentuk akar. Karakter anatomi tumbuhan yang dapat diamati salah satunya yaitu struktur sel serta jaringan penyusun tumbuhan tersebut. Struktur anatomi yang dapat dijadikan acuan dalam karakterisasi tumbuhan salah satunya adalah struktur jaringan epidermis (Sa'adah, 2015). Perbedaan karakteristik morfologi serta anatomi tumbuhan bisa disebabkan oleh kondisi lingkungan seperti ketinggian tempat.

Menurut Hamzah (2010) Semakin tinggi suatu daerah, maka akan semakin rendah suhu udaranya. Sedangkan semakin rendah suatu daerah, maka suhu udaranya semakin tinggi. Suhu udara, kelembaban udara, sinar matahari serta angin sangat mempengaruhi proses pertumbuhan tanaman. Menurut Hemelda (2012) tumbuhan dapat memberikan banyak bukti tentang perubahan iklim. Dikarenakan adanya korelasi antara iklim dan karakter daun. Ukuran daun dan tepi daun dapat menyertakan informasi bagi proses penyesuaian tumbuhan terhadap rata-rata curah hujan serta suhu.

Salah satu tanaman yang dapat beradaptasi terhadap perbedaan suhu adalah tanaman jahe. Tanaman jahe merupakan terna tahunan, batang semu dengan tinggi sekitar 30-70 $\mathrm{cm}$. Jahe hidup merumpun, berkembang biak, dan menghasilkan rimpang, bentuk rimpang jahe beragam. Didalam rimpang jahe terdapat minyak atsiri (Rukmana, 2000). aktivitas pharmalogi jahe seperti melindungi jantung, antioksidan, antiproliferative, melindungi syaraf dan melindungi dari radang hati (Pratap, 2017).Tanaman jahe tumbuh baik di dataran tinggi maupun dataran rendah. Dari hasil observasi, tanaman jahe banyak ditanam di dua wilayah yang memiliki ketinggian tempat berbeda yaitu 
Kecamatan Tugumulyo Kabupaten Musi Rawas dan Kecamatan Selupu Rejang Kabupaten Rejang Lebong.

Semua desa/kelurahan Kecamatan tugumulyo bukanlah daerah pantai dengan ketinggian dibawah $500 \mathrm{~m}$ dpl, yaitu berkisar antara 125-140 meter. Wilayah ini termasuk kedalam wilayah dengan dataran yang rendah (Pemkab Musi Rawas 2014). Menurut BPS Kabupaten Rejang Lebong (2012) secara topografi, adalah daerah berbukit-bukit dengan ketinggian 100 hingga lebih dari 1000 mdpl. Seluas 44,84\% wilayah ini berada pada ketinggian $1000 \mathrm{~m}$ dpl yang menyebar di seluruh kecamatan terutama Kecamatan Padang Ulak Tanding, Sindang Beliti Ilir, Selupu Rejang, Sindang Beliti Ulu, Bermani Ulu Raya, Sindang Kelingi, dan Curup.

Hasil karakteristik morfologi dan anatomi bisa dijadikan booklet untuk mata kuliah morfologi dan anatomi tumbuhan. Booklet adalah sebuah buku kecil yang memiliki paling sedikit 5 halaman tetapi tidak melebihi 48 halaman diluar hitungan sampul. Booklet berisikan informasi-informasi penting, yang isinya harus jelas, tegas, mudah dimengerti dan akan lebih menarik jika booklet tersebut disertai dengan gambar.

\section{METODE PENELITIAN}

Penelitian dilakukan di Desa E Wonokerto Kecamatan Tugumulyo Kabupaten Musi Rawas dan Desa Karang Jaya Kecamatan Selupu Rejang Kabupaten Rejang Lebong untuk pengambilan sampel. Waktu penelitian dilaksanakan selama \pm satu minggu pada bulan Juli-Agustus 2018. Pengamatan karakteristik morfologi dan anatomi serta pembuatan herbarium dilakukan di Laboratorium Biologi STKIP PGRI Lubuklinggau. Pembuatan booklet dapat dilakukan setelah mendapatkan hasil pengamatan karakteristik morfologi dan anatomi. Bahan yang digunakan untuk pengamatan morfologi antara lain: sampel jahe, alkohol 70\%, koran, karton, dan bingkai. Bahan yang digunakan untuk pengamatan anatomi antara lain: eidermis daun, epidermis batang semu, epidermis rimpang, dan aquades. Penelitian ini menggunakan metode penelitian kualitatif, dengan metode pengambilan sampel secara purposive sampling yaitu pengambilan sampel sumber data dengan pertimbangan tertentu (Sugiyono, 2013). Seperti pada penelitian ini pengambilan sampel jahe pada kedua tempat yang memiliki ketinggian berbeda, yaitu di desa E Wonokerto merupakan dataran rendah dan desa Karang Jaya merupakan dataran tinggi, kemudian kedua sampel diamati morfologi dan antominya.

\section{Prosedur Penelitian}

\section{Observasi}

Metode observasi yaitu metode pengamatan langsung di lokasi penelitian yang bertujuan untuk memperoleh data penelitian. Yaitu dengan mengadakan pengamatan dari dekat, mencatat dan mengambil dokumen berupa foto. Observasi 
dilakukan di Desa E Wonokerto Kecamatan Tugumulyo dan Desa Karang Jaya Kecamatan Selupu Rejang.

\section{Wawancara}

Metode wawancara digunakan untuk memperoleh informasi dari narasumber sebelum penelitian. Proses wawancara dengan mengajukan beberapa pertanyaan yang bertujuan untuk memperoleh informasi data lisan dari responden yaitu data mengenai daerah yang paling tinggi dan paling rendah, tempat yang memiliki banyak tanaman jahe, jenis-jenis jahe yang ada di daerah tersebut, dan apakah sudah pernah dilakukan penelitian yang sama di daerah tersebut. Narasumber wawancara adalah pegawai di kantor kecamatan di Tugumulyo dan Selupu Rejang serta beberapa warga dari desa E Wonokerto dan Karang Jaya.

\section{Teknik Karakterisasi}

Karakterisasi yang diamati pada penelitian ini meliputi karakter morfologi dan anatomi jahe secara kuantitatif dan kualitatif. Karakter kuantitatif merupakan karakter yang dapat diukur, seperti panjang dan lebar daun, panjang batang, dan sebagainya. Karakter kualitatif meliputi karakter yang tidak dapat diukur, seperti bentuk daun, bentuk tepi daun, warna daun, bentuk batang, warna batang, bentuk akar, warna akar, dan sebagainya. Tanaman jahe yang dipilih menjadi sampel adalah tanaman jahe yang berumur \pm 8 bulan dan tanaman jahe yang sehat, dengan ciri-ciri batang tanaman terlihat besar, daun terlihat hijau segar, dan rimpang terlihat besar dan mulus.

\section{Kajian Dokumen}

Menurut Sugiyono (2013) Dokumen bisa berbentuk tulisan, gambar atau karya-karya monumental dari seseorang yang dapat mendukung penelitian. Seperti buku Morfologi Tumbuhan karya Gembong Tjitrosoepomo (2009), Morfologi Tumbuhan karya Dewi Rosanti (2013) serta buku Anatomi Tumbuhan karya Sri Mulyani E.S (2006), selain itu juga dokumentasi pribadi, jurnal penelitian seperti jurnal penelitian Sa'adah (2015) tentang Karakteristik Morfologi dan Anatomi Selada Air (Nasturtium sp) di Kabupaten Batang dan Semarang Sebagai Sumber Belajar dalam Mata Kuliah Morfologi dan Anatomi Tumbuhan., atau karya ilmiah lain yang relevan.

\section{Kuesioner (Angket)}

Teknik kuesioner atau angket adalah salah satu teknik pengumpulan data dengan cara memberikan pertanyaan atau pernyataan dalam bentuk tertulis kepada responden untuk dijawabnya (2013). Angket dibuat dengan skala Likert. Responden yang dipilih meliputi ahli materi, ahli desain, ahli bahasa, dan mahasiswa. Angket ini digunakan untuk menilai produk hasil karakteristik 
morfologi dan anatomi jahe, apakah layak digunakan atau tidak sebagai booklet untuk mata kuliah morfologi dan anatomi tumbuhan.

\section{HASIL PENELITIAN}

\section{Hasil Penelitian Karakteristik Morfologi Jahe di Dataran Tinggi dan Dataran Rendah}

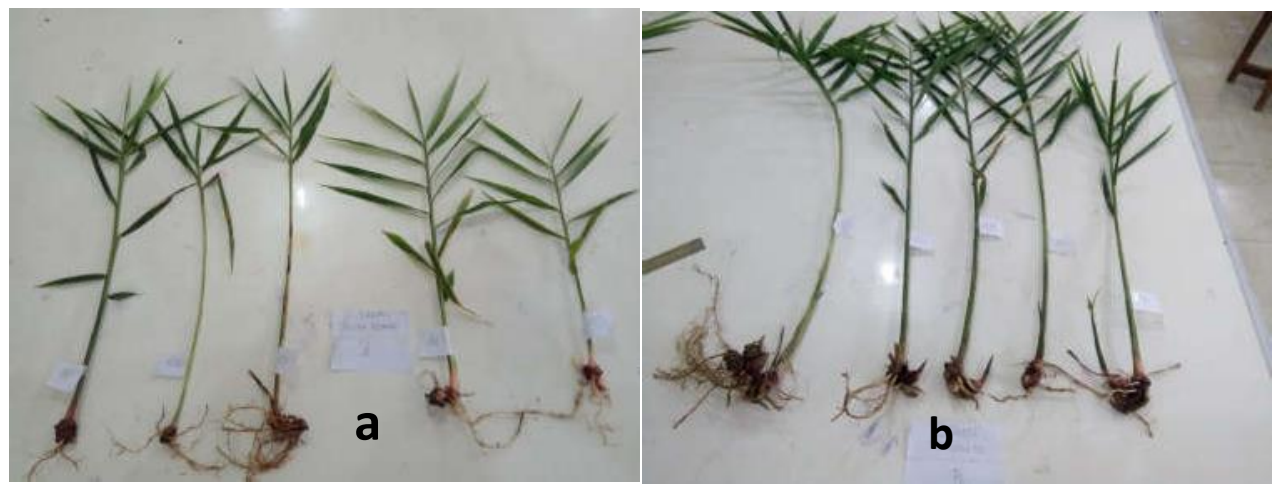

Gambar 1. Tanaman Jahe Dataran Tinggi dan Dataran Rendah (a. Desa Karang Jaa, b. Desa E Wonokerto)

Tabel 1. Hasil Pengukuran Faktor Abiotik

\begin{tabular}{clcc}
\hline No & \multicolumn{1}{c}{ Faktor Abiotik } & Desa Karang Jaya & Desa E Wonokerto \\
\hline 1 & Ketinggian Tempat & $1113 \mathrm{mdpl}$ & $136 \mathrm{Mdpl}$ \\
\hline 2 & Suhu Udara & $24^{\circ} \mathrm{C}$ & $330 \mathrm{C}$ \\
\hline 3 & Kelembaban Udara & $76 \%$ & $62 \%$ \\
\hline 4 & pH Tanah & 6 & 6 \\
\hline
\end{tabular}

Tabel 2. Karakter Kuantitatif Morfologi daun Jahe

\begin{tabular}{clcc}
\hline No & Karakter yang diukur & $\begin{array}{c}\text { Dataran Tinggi } \\
\text { (Desa Karang Jaya) }\end{array}$ & $\begin{array}{c}\text { Dataran Rendah } \\
\text { (Desa E Wonokerto) }\end{array}$ \\
\hline 1 & Panjang daun & 18,5 & 25,4 \\
\hline 2 & Lebar daun & 1,8 & 2,4 \\
\hline
\end{tabular}

Tabel 3. Karakter Kualitatif Morfologi Daun Jahe

\begin{tabular}{clcc}
\hline No & \multicolumn{1}{c}{$\begin{array}{c}\text { Karakter yang } \\
\text { diamati }\end{array}$} & $\begin{array}{c}\text { Dataran Tinggi } \\
\text { (Desa Karang Jaya) }\end{array}$ & $\begin{array}{c}\text { Dataran Rendah } \\
\text { (Desa E Wonokerto) }\end{array}$ \\
\hline 1 & Warna daun & Hijau kekuningan & Hijau pekat \\
\hline 2 & Bangun daun & Lanset & Lanset \\
\hline 3 & Tepi daun & Rata & Rata \\
\hline 4 & Ujung daun & Meruncing & Meruncing \\
\hline 5 & Pangkal daun & Runcing & Runcing \\
\hline 6 & Pertulangan daun & Sejajar & Sejajar \\
\hline 7 & Tekstur permukaan daun & Licin & Licin \\
\hline 8 & Tipe daun & Daun tunggal & Daun tunggal \\
\hline
\end{tabular}


Tabel 4. Karakter Kuantitatif Morfologi Batang Semu Jahe

\begin{tabular}{cccc}
\hline No & $\begin{array}{c}\text { Karakter yang } \\
\text { diukur }\end{array}$ & $\begin{array}{c}\text { Dataran Tinggi (Desa } \\
\text { Karang Jaya) }\end{array}$ & $\begin{array}{c}\text { Dataran Rendah } \\
\text { (Desa E Wonokerto) }\end{array}$ \\
\hline 1 & Panjang batang & 38,1 & 70,1 \\
\hline
\end{tabular}

Tabel 5. Karakter Kualitatif Morfologi Batang Semu Jahe

\begin{tabular}{clcc}
\hline No & \multicolumn{1}{c}{$\begin{array}{c}\text { Karakter yang } \\
\text { diamati }\end{array}$} & $\begin{array}{c}\text { Dataran Tinggi } \\
\text { (Desa Karang Jaya) }\end{array}$ & $\begin{array}{c}\text { Dataran Rendah } \\
\text { (Desa E Wonokerto) }\end{array}$ \\
\hline 1 & Jenis batang & Batang semu & Batang Semu \\
\hline 2 & Bentuk batang & Bulat & Bulat \\
\hline 3 & Warna batang & Hijau pucat & Hijau Pekat \\
\hline 4 & Jenis percabangan & Monopodial & Monopodial \\
\hline 5 & Permukaan batang & Licin & Licin \\
\hline 6 & Tekstur batang & Batang basah & Batang basah \\
\hline
\end{tabular}

Tabel 6. Karakter Kuantitatif Morfologi Akar Jahe

\begin{tabular}{cccc}
\hline No & Karakter yang diukur & $\begin{array}{c}\text { Dataran Tinggi } \\
\text { (Desa Karang Jaya) }\end{array}$ & $\begin{array}{c}\text { Dataran Rendah } \\
\text { (Desa E Wonokerto) }\end{array}$ \\
\hline 1 & Panjang akar & 11 & 12,4 \\
\hline
\end{tabular}

Tabel 7. Karakter Kualitatif Morfologi Akar Jahe

\begin{tabular}{clcc}
\hline No & \multicolumn{1}{c}{$\begin{array}{c}\text { Karakter yang } \\
\text { diamati }\end{array}$} & $\begin{array}{c}\text { Dataran Tinggi } \\
\text { (Desa Karang Jaya) }\end{array}$ & $\begin{array}{c}\text { Dataran Rendah } \\
\text { (Desa E Wonokerto) }\end{array}$ \\
\hline 1 & Tipe akar & Serabut & Serabut \\
\hline 2 & Bentuk akar & Bulat memanjang & Bulat memanjang \\
\hline 3 & Warna akar & Putih kecoklatan & Putih kecoklatan \\
\hline
\end{tabular}

Tabel 8. Karakter Kuantitatif Morfologi Rimpang Jahe

\begin{tabular}{clcc}
\hline No & Karakter yang diukur & $\begin{array}{c}\text { Dataran Tinggi } \\
\text { (Desa Karang Jaya) }\end{array}$ & $\begin{array}{c}\text { Dataran Rendah } \\
\text { (Desa E Wonokerto) }\end{array}$ \\
\hline 1 & Panjang rimpang & 4,1 & 6 \\
\hline 2 & Lebar rimpang & 2,3 & 3,2 \\
\hline
\end{tabular}

Tabel 9. Karakter Kualitatif Morfologi Rimpang Jahe

\begin{tabular}{clcc}
\hline No & Karakter yang diamati & $\begin{array}{c}\text { Dataran Tinggi } \\
\text { (Desa Karang Jaya) }\end{array}$ & $\begin{array}{c}\text { Dataran Rendah } \\
\text { (Desa E Wonokerto) }\end{array}$ \\
\hline 1 & Bentuk rimpang & Berbentuk jemari & Berbentuk jemari \\
\hline 2 & $\begin{array}{l}\text { Warna kulit } \\
\text { rimpang }\end{array}$ & Merah & Merah \\
\hline 3 & Warna daging rimpang & Putih kekuningan & Putih kekuningan \\
\hline
\end{tabular}




\section{Hasil Penelitian Karakteristik Anatomi Daun Jahe di Dataran Tinggi dan Dataran Rendah}

Tabel 10. Karakter Anatomi Jaringan Epidermis Daun Jahe

\begin{tabular}{|c|c|c|}
\hline $\begin{array}{l}\text { Karakteristik } \\
\text { Anatomi }\end{array}$ & $\begin{array}{c}\text { Dataran Tinggi (Desa Karang } \\
\text { Jaya) }\end{array}$ & $\begin{array}{c}\text { Dataran Rendah (Desa E } \\
\text { Wonokerto) }\end{array}$ \\
\hline \multirow[t]{2}{*}{$\begin{array}{l}\text { Epidermis } \\
\text { Daun } \\
\text { (Perbesaran } \\
10 x \text { 40x) }\end{array}$} & & \\
\hline & Sel Epidermis Stomata & Sel Epidermis Stomata \\
\hline Deskripsi & 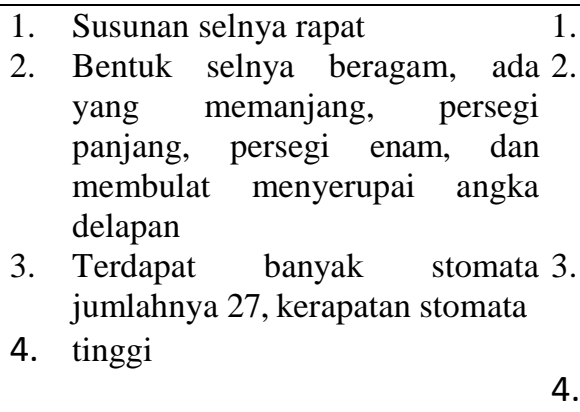 & 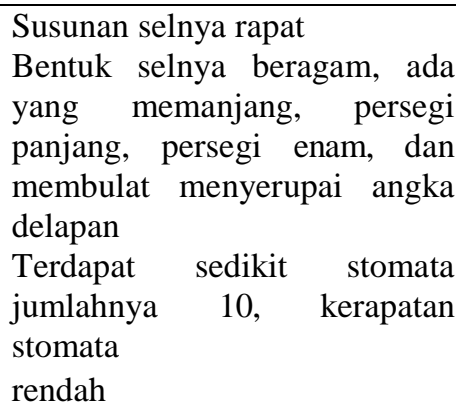 \\
\hline
\end{tabular}

Tabel 11. Karakter Anatomi Jaringan Epidermis Batang Semu Jahe

\begin{tabular}{|c|c|c|}
\hline $\begin{array}{c}\text { Karakteristik } \\
\text { Anatomi }\end{array}$ & $\begin{array}{c}\text { Dataran Tinggi } \\
\text { (Desa Karang Jaya) }\end{array}$ & $\begin{array}{c}\text { Dataran Rendah } \\
\text { (Desa E Wonokerto) }\end{array}$ \\
\hline \multirow[t]{2}{*}{$\begin{array}{l}\text { Epidermis } \\
\text { Batang Semu } \\
\text { (Perbesaran 10x } \\
\text { 40x) }\end{array}$} & & \\
\hline & Sel Epidermis & Sel Epidermis \\
\hline Deskripsi & $\begin{array}{l}\text { 1. Susunan selnya rapat } \\
\text { 2. Bentuk selnya beragam, ada yang } \\
\text { persegi enam, persegi panjang, } \\
\text { dan bulat }\end{array}$ & $\begin{array}{l}\text { 1. Susunan selnya rapat } \\
\text { 2. Bentuk selnya beragam, ada } \\
\text { yang persegi enam, persegi } \\
\text { panjang, dan bulat }\end{array}$ \\
\hline
\end{tabular}


Tabel 12 Karakter Anatomi Jaringan Epidermis Rimpang Jahe

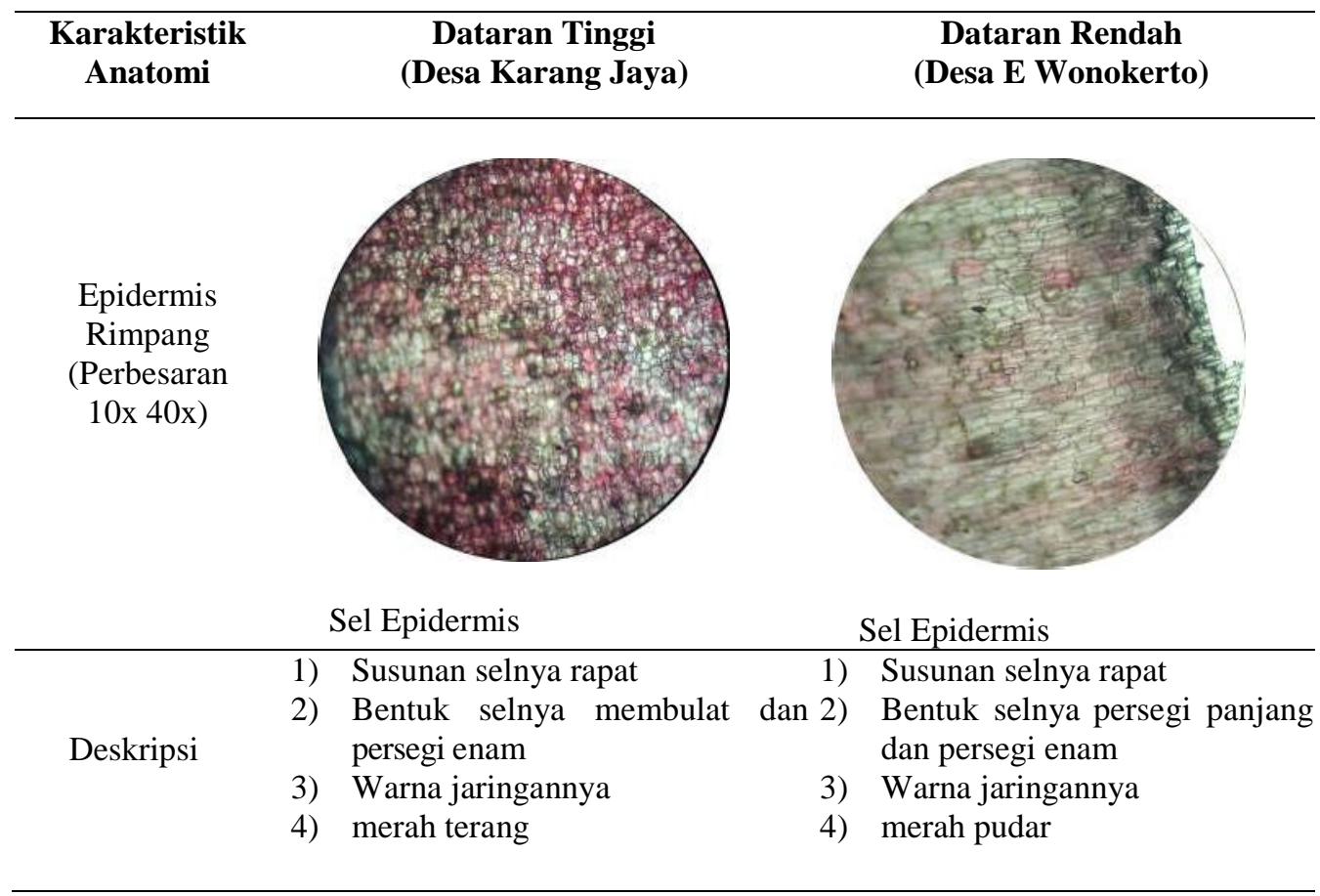

\section{Hasil Penilaian Booklet}

Hasil persentase penilaian oleh ahli materi, ahli bahasa, dan ahli desain adalah $84 \%$, berdasarkan kualifikasi tersebut menyatakan bahwa booklet sudah valid.

\section{PEMBAHASAN}

Tanaman jahe yang ditana di Desa Karang Jaya Kecamatan Selupu Rejang, suhu udaranya rendah, dan udaranya lembab, memiliki morfologi tanaman jahe merah yang batangnya lebih pendek, daunnya pendek dan tidak lebar serta memiliki batang hijau muda dan daun yang terlihat hijau kekuningan. Sedangkan, tanaman jahe yang ditanam di Desa E Wonokerto Kecamatan Tugumulyo, suhu udaranya tinggi, dan udaranya tidak lembab, memiliki morfologi tanaman jahe merah yang batangnya lebih tinggi, daunnya panjang dan lebar serta memiliki batang hijau pekat dan daun yang terlihat hijau pekat. Tumbuhan merupakan organisme yang tidak dapat berpindah tempat, sehingga tumbuhan harus beradaptasi dengan kondisi lingkungan tempat tumbuhan tersebut tumbuh. Perbedaan kondisi lingkungan pada tempat tumbuh dapat mempengaruhi struktur, fisiologi, dan reproduksi suatu tumbuhan (Hemelda, 2012).

Faktor lingkungan yang mempengaruhi variasi dari suau spesies tumbuhan dapat berupa faktor abiotik dan biotik. Faktor abiotik meliputi suhu, kelembaban, curah hujan, tanah, dan cahaya. Faktor biotik meliputi interaksi intraspesifik dan interaksi interspesifik, seperti predasi dan kompetisi (Hemelda, 2012). Berdasarkan hasil pengukuran faktor abiotik, Desa Karang Jaya Kecamatan 
Selupu Rejang berada pada ketinggian 1113 mdpl, suhu udara $24^{\circ} \mathrm{C}$, pH tanah 6 , dan dengan kelembaban udara 76\%. Sedangkan Desa E Wonokerto Kecamatan Tugumulyo berada pada ketinggian $136 \mathrm{mdpl}$, suhu udara $33^{\circ} \mathrm{C}, \mathrm{pH}$ tanah 6 , dan kelembaban udaranya $62 \%$. Suhu pada kedua desa tersebut masih tergolong suhu yang normal, karena untuk tanaman jahe dapat tumbuh pada kisaran suhu 23$36^{\circ} \mathrm{C}$. Variasi yang terjadi karena adanya kondisi lingkungan menunjukkan bahwa suatu tumbuhan melakukan adaptasi (Hemelda, 2012). Tumbuhan dapat menyediakan banyak bukti mengenai perubahan iklim. Hal tersebut dikarenakan adanya korelasi antara iklim dan karakter daun. Ukuran daun dan tepi daun dapat menyediakan informasi bagi proses adaptasi tumbuhan terhadap rata-rata curah hujan dan suhu. Faktor-faktor iklim sangat berinteraksi satu sama lain sepanjang gradien ketinggian, mempengaruhi baik morfologi, anatomi, dan fisiologi tumbuhan (Hemelda, 2012). Faktor yang mempengaruhi perbedaan stomata adalah kondisi lingkungan yang ada pada saat perbedaan stomata di embrio pucuk daun sangat mempengaruhi proses ini. Tersedianya air, intensitas cahaya, dan suhu memperlihatkan pengaruh penting (Zelitch, 2018).

Karakter anatomi yang diamati adalah jaringan epidermis daun, batang semu dan akar. Baik di Desa Karang Jaya Kecamatan Selupu Rejang maupun Desa E Wonokerto Kecamatan Tugumulyo, susunan selnya sama-sama rapat dan bentuk selnya beragam. Karakter anatomi kedua tempat hampir sama, hanya saja pada jaringan epidermis daun tanaman jahe di Desa Karang Jaya stomatanya lebih rapat. Susunan sel pada epidermis rimpang di Desa Karang Jaya lebih rapat dan warna jaringan epidermis rimpang di Desa Karang Jaya lebih merah terang.

\section{Hasil Penilaian Booklet}

Hasil penilaian ahli

Validasi telah dilakukan oleh tiga validator yaitu validator ahli materi, ahli desain, dan ahli bahasa. Hasil validasi dari masing-masing validator menunjukkan bahwa booklet yang dikembangkan sudah valid. Validator ahli materi booklet adalah validasi materi mendapatkan persentase sebesar 92,5\%. Validator ahli desain yaitu persentase yang didapatkan dari validator ahli desain adalah sebesar $87,5 \%$. Validator bahasa dalam booklet ini adalah persentasi penilaian ahli bahasa adalah $72,5 \%$.

\section{Hasil Penilaian Angket Mahasiswa}

Penilai angket adalah mahasiswa biologi yang telah menempuh mata kuliah morfologi dan anatomi tumbuhan. Penilaian yang dilakukan merupakan uji coba skala kecil menggunakan 10 mahasiswa. Persentase penilaiannya adalah $92,5 \%$. Tidak ada saran yang diberikan yang menandakan booklet telah dianggap praktis digunakan sebagai informasi dan sumber bacaan atau sumber belajar bagi mahasiwa khusunya dalam mata kuliah morfologi dan anatomi tumbuhan. 


\section{SIMPULAN}

Hasil penelitian menunjukkan adanya perbedaan morfologi dan anatomi tanaman jahe berdasarkan perbedaan ketinggian tempat, tanaman jahe di Kecamatan Tugumulyo memiliki daun terpanjang dan terlebar, batang tertinggi, akar terpanjang, rimpang terpanjang dan terlebar, dan warna daun dan batang yang hijau pekat. Tanaman jahe di Kecamatan Selupu Rejang memiliki kerapatan stomata yang tinggi. Tanaman jahe lebih cocok ditanam di dataran rendah dengan suhu udara tinggi, kelembaban yang rendah. Persentase hasil penilaian booklet secara keseluruhan dari segi materi, media, bahasa, dan uji coba kelas kecil adalah $86,2 \%$, sehingga dapat dinyatakan bahwa desain booklet sudah valid dan praktis.

\section{DAFTAR PUSTAKA}

BPS Kabupaten Rejang Lebong. (2012). Letak Geografis Kota Curup. http://lebongkab.bps.go.id (Diakses 17 Maret 2018)

Farm, A. (2013). Ginger (Zingiber officinale Rosec.) Production, Postharvest Handling, Processing and Marketing: A Comprehensive Extension Package Manual. Ethiopia: Hawassa

Gembong, T. (2009). Morfologi tumbuhan. Yogyakarta: Gadjah Mada University Press.

Hamzah, M., F. (2010). Studi Morfologi dan Anatomi Daun Edelweis Jawa (Anaphalis javanica) Pada Zona Ketinggian yang Berbeda di Taman

Hemelda, N. M. (2012). Pengaruh Gradien Ketinggian terhadap Variasi Morfologi Rotan Calamus javensis Blume(Aracaceae) di Gunung Kendeng,Taman Nasional Gunung Halimun Salak, Jawa Barat Depok: Departemen Biologi Fakultas Matematika Dan Ilmu Pengetahuan Alam Universitas Indonesia.

Pemkab Musi Rawas. (2014). Geografis Kabupaten Musi Rawas Kecamatan Tugumulyo.http://www.musirawaskab.go.id (Diakses 17 Maret 2018)

Pratap, S., R. (2017). Ginger: A Potential Neutraceutical, An Updated Review. International Journal of Pharmacognosy and Phytochemical Research 9(9):1227-1238

Rukmana, R. (2000). Usaha Tani Jahe. Yogyakarta: Kanisius

Sa'adah, L. (2015). Karakteristik Morfologi dan Anatomi Selada Air (Naturtium sp)di Kabupaten Batang dan Semarang sebagai Sumber Belajar dalam Mata Kuliah Morfologi dan Anatomi Tumbuhan. Skripsi. Semarang: UIN Walisongo Semarang

Sri M., E., S. (2006). Anatomi Tumbuhan. Bandung: ITB Press

Sugiyono. (2013). Metode Penelitian Pendidikan (Pendekatan Kuantitatif, Kualitatif, dan $R \& D)$. Bandung: Alfabet

Warianto, C. (2011). Biologi sebagai Ilmu. Skp.unair.ac.id (Diakses 13 Maret 2018).

Zelitch, I. (2018). Stomata and Water Relations in Plants. New Haven: The Constitut Agricultural Experiment Station 